\title{
Państwo komunistyczne a Kościół w publicystyce Józefa Mackiewicza
}

Był świadkiem swojej epoki, intelektualistą o rzadko spotykanym dorobku i głębi myśli. Jego znakomita proza osiągnęła wyżyny, chociaż zarzucano jej wiele, najczęściej były to zarzuty absurdalne, niekompetentne lub świadczące o złej woli i tendencyjnej ocenie jego dorobku twórczego. Był bodaj największym polskim pisarzem drugiej połowy XX w., intelektualistą o rzadkiej głębi postrzegania rzeczywistości. Droga donikąd, jedna z wielu powieści Mackiewicza, to magnum opus, genialna wprost analiza ponurej komunistycznej rzeczywistości. „Żaden pisarz na emigracji nie zaznał takich napaści i szkalowań co Józef Mackiewicz. Zarzucano mu kolaborację z Litwinami, potem z Niemcami (jemu, który był furmanem za ich okupacji), poniżanie w swej powieści wojska polskiego w 1920 r. (służył całą wojnę jako prosty żołnierz w kawalerii), ubliżanie $\mathrm{AK}$, bezczeszczenie polskich kobiet, szarganie Piłsudskiego, grubiaństwo, kalanie, bluźnierstwa, zła polszczyzna, nieznajomość gramatyki..." - napisał po śmierci pisarza jego przyjaciel (także daleki krewny) Karol Zbyszewski, świetny publicysta i dziennikarz radiowy związany przez wiele lat z Radiem Wolna Europa ${ }^{1}$.

Na szczęście wraz z upływem lat rosła liczba tych zafascynowanych nieprzeciętną osobowością Mackiewicza, a nade wszystko tych, którzy obiektywnie, sine ira et studio, potrafili ocenić jego twórczy dorobek. Jego dzieło poddawano ocenom za życia i po śmierci: „pobił swoich współzawodników

\footnotetext{
${ }^{1}$ Muzeum Polskie w Rapperswilu (MPR), Spuścizna Józefa Mackiewicza, sygn. 114 (Materiały biograficzne), k. 5. Wycinek prasowy: K. Zbyszewski, Najbardziej niezależny pisarz Emigracji, „Dziennik Polski” (Londyn) 1985 z 13 lutego; G. Łukomski, Józef Mackiewicz (1902-1985). Intelektualista u źródet antykomunizmu ideowego, Warszawa-Poznań-Londyn 2011, s. 176-178 .
} 
piszących bardziej wyszukaną prozą, Pobił artystycznie. Można zastosować do nich powiedzenie sowieckiego, [czy w tym przypadku raczej rosyjskiego G.Ł.] żołnierzyka: «Francuzy w szełkach, no wojnu proigrali» [ros.: Francuzi $\mathrm{w}$ jedwabiach, ale wojnę przegrali - G.Ł.]. Jego proza jest zwarta, oszczędna, funkcjonalna. Widzi się co opisuje, a już specjalnie krajobraz jego okolic. Pośród znanych mi polskich literatów nikt tak nie pisał. Ale i Prus i Żeromski byli $\mathrm{w}$ porównaniu z nim literatami zawodowymi. Szlachcic szaraczkowy, jak go nazwałem, z tych upartych, wzgardliwych, zaciekłych milczków, pisał na złość. Na złość całemu światu, który czarne nazywa białym i nie ma nikogo, kto by założył veto. I właśnie w tej pasji jest sekret jego stylu"2 ${ }^{2}$ Tak o pisarstwie Mackiewicza napisał Czesław Miłosz. Bez wątpienia czerpał swoją siłę i kształtował osobowość twórczą także z warunków przyrodniczych kraju rodzinnego, gdzie roślinność jest zróżnicowana i bujna wspaniałą obfitością północnej Europy, lata krótkie, długie i mroźne zimy, a nad całością dominuje niskie, często spowite chmurami niebo.

Dodajmy, był pisarzem realistą, z „zaciekłością", jak powiedział Miłosz, odtwarzającym prawdę poprzez odpowiedź na pytanie "jak to naprawdę było?" W dochodzeniu do jej sedna stał się niemal doskonałym badaczem dziejów, historykiem na miarę klasyków historiografii, w sposób metodyczny odkrywającym przeszłość. „Wyznaczano historii funkcję sądzenia przeszłości, pouczania współczesnych dla pożytku późniejszych pokoleń; do tak wzniosłych zadań, nie pretenduje niniejszy zarys, pragnie on jedynie opowiedzieć, jak to właściwie było? [Er will bloss sagen, wie es eigentlich gewesen?]"3. Owo klasyczne już stwierdzenie mogłoby być mottem wielu prac Józefa Mackiewicza. Powyższa formuła metodologiczna, autorstwa jednego z klasyków nauki historycznej - Leopolda von Rankego - zakładała programowy obiektywizm. Historia, według niego, ma konstatować fakty na podstawie krytycznej analizy źródeł, a historyk obserwować owe fakty i zjawiska oraz bez zbędnych emocji starać się je zrozumieć. Była to także metoda pracy Mackiewicza jako pisarza historycznego. I choć wielkie są jego dokonania literackie, to nie mniej wielkie na tym właśnie polu. Był bowiem twórcą niezwykle zdyscyplinowanym i systematycznym, posiadał wszelkie predyspozycje także do pracy naukowej. Spuściznę pozostawił ogromną, w sensie objętości, a zwłaszcza głębi merytorycznej.

Przywołajmy raz jeszcze Czesława Miłosza: „Józef Mackiewicz widział groby katyńskie i napisał, co zobaczył. Przypadkiem był też świadkiem, jak odbywało się mordowanie Żydów przez Niemców w Ponarach, i też zostawił rzeczowy raport. I dopóki będzie istnieć polskie piśmiennictwo, te dwa zapisy grozy dwudziestego wieku powinny być stale przypominane, po to,

\footnotetext{
2 Cz. Miłosz, Rok myśliwego, Kraków 2001, s. 250.

${ }^{3}$ L. Ranke, Sämtliche Werke, Leipzig 1874, t. 33, s. VII.
} 
żeby dostarczały miary wtedy, kiedy literatura zbytnio oddala się od rzeczywistości" ${ }^{4}$.

Równie znakomita była jego publicystyka, która nierozdzielnie splatała się z literaturą. "Jak to jest możliwe?", pytał retorycznie i wielokrotnie w swoich tekstach Mackiewicz. W pytaniu tym znajdujemy istotę jego politycznego i jednocześnie humanistycznego myślenia, domagającego się respektowania ustalonych w naszej kulturze reguł, które tak wielu miało i ma dotąd za nic. Był z Mackiewicza bez wątpienia wyjątkowej miary homo politicus. Publicystyce politycznej poświęcał coraz więcej swego cennego czasu. Odbywało się to często, przyznać należy, kosztem pracy literackiej. Bez wątpienia stawał się coraz bardziej publicystą politycznym, inteligentnym i błyskotliwym polemistą, o ogromnym poczuciu humoru i dystansu do podejmowanych spraw, co bardzo szybko dostrzeżono w kręgu osób zainteresowanych i kompetentnych.

Był także, co dla nas bardzo ważne, w latach dwudziestych i trzydziestych XX w. na łamach wileńskiego „Słowa” prekursorem polskiej i światowej sowietologii, w czasach, gdy na zachodzie Europy (z wyjątkiem Niemiec) nikomu się o niej nawet nie śniło, tym bardziej w Stanach Zjednoczonych. Problem zawarty $\mathrm{w}$ tytule rozpatrujemy zatem na dwóch płaszczyznach: stosunku państwa komunistycznego do religii, jako państwa nowego, nieznanego dotąd w praktyce społecznej, i - po wtóre - relacji polskiego państwa komunistycznego do religii i Kościoła jako instytucji. Oba przypadki interesowały Mackiewicza w sposób szczególny i zajmowały istotne miejsce w jego twórczości literackiej oraz publicystycznej.

Relacjom między bolszewizmem a religią oraz największym jej instytucjonalnym uosobieniem - Watykanem, poświęcił obszerny tekst zatytułowany Bolszewizm $i$ Watykan ${ }^{5}$. Była to jakby zapowiedź zainteresowania problematyką, której znaczenie rosło $\mathrm{w}$ drugiej połowie XX w. Występował przeciwko tradycyjnemu postrzeganiu bolszewizmu, zwłaszcza przez teologów i filozofów katolickich, przez pryzmat samego przewrotu w 1917 r. i w czasie kilku następnych lat, gdy był on u swego zarania antychrześcijański i antyreligijny w ogóle, co wynikało z samej jego doktryny. Po kilku latach sytuacja uległa zmianie, gdyż pragmatyka działania narzuciła nowe rozwiązania. Wobec totalnej walki bolszewików z „resztą świata” walka z Bogiem z konieczno-

${ }^{4}$ Cz. Miłosz, dz. cyt., s. 240. Identyczną myśl wyraził Miłosz w liście do Mackiewicza, wystawiając nader pozytywną opinię o pracy Fakty, przyroda i ludzie...: „Mnie naturalnie najbardziej w niej nęci obecność Wilna, jak i to, że jest Pan - podobnie jak w powieściach, jedynym polskim autorem do tego stopnia wolnym od nacjonalizmu. No, a dwa rozdziały - o Ponarach i Katyniu powinny wejść w skład każdej przyszłej chrestomatii literatury polskiej...". MPR, Spuścizna, sygn. 138, k. 34 (korespondencja od Czesława Miłosza, list z 12 czerwca 1984 r.).

${ }^{5}$ J. Mackiewicz, Bolszewizm i Watykan, „Wiadomości” (Londyn) 1949, nr 35/36 (178/179); J. Mackiewicz, B. Toporska, Droga Pani ..., [w:] tegoż, Dzieła, Londyn 1984, s. 335-344. 
ści zeszła na plan dalszy. Poczyniono zatem pewne ustępstwa i koncesje „dla uspokojenia sumień wielkich demokracji podczas wojny, a w pierwszych latach po jej zakończeniu byliśmy świadkami jawnej współpracy chrześcijańsko-bolszewickiej na terenie wspólnego tzw. demokratycznego frontu «antyfaszystowskiego»" 6 .

Wbrew potocznym opiniom, bolszewizm nie jest rodzajem „nowej religii", z kilku powodów, m.in. dlatego, iż stara się wyplenić z duszy ludzkiej to, co stanowi o radości życia doczesnego, nie zaś wiecznego. Choć zmusza człowieka do pełnego poświęcenia się dla idei, jak chrześcijaństwo dla idei Boga, trudno taką ideologię nazwać "kontrreligijną" w potocznym znaczeniu tego słowa, gdyż „bolszewizm powstał nie z walki z Bogiem, lecz z walki z człowiekiem, tzn. $z$ jego przyrodzonym prawem wolnej woli" ${ }^{7}$.

Tak więc w latach II wojny światowej z powodów taktycznych bolszewicy nauczyli się ignorować religię, mając przed sobą cele o wiele ważniejsze. Tak było w latach 1939-1940, m.in. w Polsce i w krajach bałtyckich. „Nieoczekiwana przez nikogo tolerancja w stosunku do kleru wypływała niewątpliwie nie tyle ze strachu przed ludnością, ile raczej z wyrachowania, aby nie drażnić jej w dziedzinie najmniej dla Sowietów istotnej" ${ }^{8}$. Niemniej jednak „bolszewizm jest wrogiem religii, ale tylko o tyle, o ile krępując wszelką naukę poza swoją, krępuje również naukę Chrystusa, Mahometa, Mojżesza. Bolszewizm jest wrogiem wszelkiej wolności pod każdą postacią, a więc naturalnie i wolności wyznania. Największym wrogiem wolności jaki kiedykolwiek w zbiorowym ustroju ludzkim istniał na globie. Wrogiem wolności słowa, wolności myśli, wolności druku, wolności czynu dobrego, wolności czynu złego, wolności poruszania się, wolności pracy, wolności lenistwa, wolności przestępstwa i wolności wiary" ${ }^{\prime \prime}$.

Błędem ze strony hierarchii kościelnej i samego Watykanu było niedocenianie niebezpieczeństwa, czego wyraz stanowiła m.in. encyklika Divini Redemptoris z 19 marca 1937 r., w której papież Pius XI potępił „bezbożny komunizm" - lecz ukazała się ona - jak uważał - o kilkadziesiąt lat za późno, a ponadto za mało dobitnie artykułowała problem. „W lekceważeniu okazywanym przez stronę bolszewicką Kościołowi tkwi największe niebezpieczeństwo, niewątpliwie stokroć razy groźniejsze od otwartych prześladowań á la Neron. Niedostrzeganie tego niebezpieczeństwa przez hierarchię kościelną wszystkich wyznań było największym błędem, jakiego się dopuścić mogły, nie tylko z punktu widzenia reprezentowanych przez nie zasad, ale i tzw. realnej polityki. Wobec bolszewizmu na nic zda się taktyka kompromisu czy

\footnotetext{
6 Tamże, s. 336.

7 Tamże, s. 337.

8 Tamże, s. 338.

${ }^{9}$ Tamże, s. 339-340.
} 
«przeczekania»"10 - przestrzegał Mackiewicz. Powojenne zabiegi sowieckie zmierzające do likwidacji kościołów w państwach "nowych demokracji” były jedynie konsekwentnym etapem na drodze do ostatecznej sowietyzacji, po uprzednim rozprawieniu się z opozycją świecką. Zatem tam, gdzie ta opozycja jest silniejsza, opóźnia się likwidacja Kościoła jako instytucji.

Pełen wewnętrznych paradoksów system sowiecki, wbrew utrwalonym stereotypom, kształtowanym przez własną propagandę, nigdy nie był wewnętrznie skonsolidowany, co w ostateczności najbardziej przyczyniło się do jego rozpadu. Polska należała do krajów, gdzie niekonsekwencje i sprzeczności systemu były największe, podobnie jak społeczny opór wobec nowej, narzuconej władzy, mimo prowadzonej przez państwo totalitarne na szeroką skalę polityki terroru i zbrodni. Wraz z upływem lat konwulsje systemu stawały się coraz bardziej spektakularne. Do walki o władzę w szeregach „partii wewnętrznej", jaką w istocie była PZPR (archetyp takiej partii stworzył w świetnej literacko formie George Orwell, 1903-1950, w powieści Rok 1984), doszło po śmierci Józefa Stalina (5 marca 1953 r.). Narastać wówczas począł w Związku Sowieckim klimat tzw. odwilży (termin zaczerpnięty od tytułu powieści pisarza sowieckiego Ilii G. Erenburga, 1891-1967, Odwilż, mówiącej o negatywnych zjawiskach "kultu jednostki”, czyli okresu osobistej władzy Stalina w Związku Sowieckim).

Wówczas właśnie, niejako w odpowiedzi na zmiany w świecie komunistycznym, istotne zmiany nastąpiły w Kościele katolickim, gdy od października 1958 r. na tron Piotrowy w Rzymie wstąpił papież Jan XXIII. Zapoczątkował on zmiany, którym po raz pierwszy dał wyraz 14 czerwca 1959 r. w przemówieniu wygłoszonym w Papieskim Kolegium greckim w Rzymie. Mówił o konieczności przystosowania Kościoła do zmieniającej się rzeczywistości. Padło wówczas po raz pierwszy określenie aggiornamento ${ }^{11}$. Słowo-klucz, które stało się symbolem przemian, obejmujących prócz życia wewnątrzkościelnego także jego relacje ze światem zewnętrznym. Ważną ich częścią stało się „udzisiejszenie" relacji ze światem komunistycznym. W praktyce chodziło o tzw. realizm polityczny („polrealizm”). Określenie to Mackiewicz, wytrawny i doświadczony sowietolog, tak wyjaśnił: „[...] słowo «realizm polityczny», czyli po prostu «realizm» znane powszechnie w mowie ludzkiej - w politycznym wydźwięku naszej ery zajmuje stanowisko eksponowane. W potocznym słownictwie Zachodu oznacza, w praktyce, respektowanie nienaruszalności komunistycznego status quo; w słownictwie Bloku Sowieckiego każda czynność, bądź wypowiedz zgodną z politycznymi interesami tegoż

10 Tamże, s. 342.

${ }^{11}$ Aggiornamento (wł.) uwspółcześnienie, aktualizacja, dostosowanie do obecnego dnia, dosłownie: udzisiejszenie, (giono - dzień). 
Bloku"12. W praktyce politycznej skutkiem nowej polityki Watykanu było nawiązanie pełnych stosunków z komunizmem, a więc faktyczne uznanie świata komunistycznego jako realny byt polityczny, wraz z jego ideologią, zmianami terytorialnymi w świecie po II wojnie światowej i masowymi zbrodniami. Najbardziej spektakularnym wyrazem „udzisiejszenia” był sobór watykański II ${ }^{13}$.

Podjęte w Kościele powszechnym zmiany dotyczyły oczywiście także Kościoła w Polsce. Dążono tu także do wypracowania swoistego modus vivendi. Kościół zyskiwał względną swobodę działania i jakiegoś wpływu na sprawy polskie za cenę zrzeczenia się znaczącej części swojej suwerenności. Było to ważne, gdyż opresja, w jakiej się znalazł, nie miała precedensu w przeszłości. Także komuniści polscy zmienili po 1956 r. strategię swych działań.

Interesujące są kulisy utworzenia Stowarzyszenia Pax, prokomunistycznej organizacji zrzeszającej świeckich działaczy katolickich ${ }^{14}$. Mackiewicz wskazał na inspiratorską w przedsięwzięciu rolę Aleksandra Bocheńskiego, w okresie II Rzeczypospolitej - publicysty o poglądach konserwatywnych. Organizacja powstała z jego koncepcji politycznej i przerodziła się niemal natychmiast $\mathrm{w}$ agenturę komunistyczną. Bocheński, oskarżany o kolaborację z Niemcami, był w istocie zwolennikiem myśli konserwatywnej i ugodowej wobec każdego, nie tylko niemieckiego najeźdźcy; nawiązywał do dziewiętnastowiecznych koncepcji Aleksandra Wielopolskiego i krakowskich Stańczyków. Po wkroczeniu Sowietów do Krakowa, zagrożony aresztowaniem, zaproponował komunistom współpracę. Ci ostatni, wówczas bardzo pragnący uwiarygodnić własną, kruchą jeszcze władzę oraz zmienić swój wi-

12 J. Mackiewicz, W cieniu Krzyża. Kabel Opatrzności, London 1994, s. 15. Praca po raz pierwszy ujrzała światło dzienne w Londynie w 1972 r., nakładem Wydawnictwa Kontra.

13 Sobór watykański II - 21. sobór powszechny, zwołany 25 grudnia 1961 r. i zainaugurowany 11 października 1962 r. przez papieża Jana XXIII. Cele soboru określił on w encyklice Ad Petri Cathedram z 29 czerwca 1959 r. - jednym z nich miało być dostosowanie dyscypliny kościelnej do wymogów czasu (aggiornamento). Odbyły się cztery sesje soborowe - Jan XXIII przewodniczył pierwszej, jego następca Paweł VI trzem kolejnym. W obradach uczestniczyło łącznie 3058 ojców soborowych i grono ekspertów; przysłuchiwali im się audytorzy (siostry zakonne i katolicy świeccy) oraz obserwatorzy wydelegowani przez chrześcijańskie wspólnoty niekatolickie (w czasie ostatniej sesji ich liczba sięgnęła 106 osób). Ogłoszono szesnaście uchwał: konstytucji, dekretów i deklaracji, w tym najważniejszą - Konstytucję dogmatyczną o Kościele". Na ten temat obszernie: S. Stępień, Sobór Watykański II i orędzie biskupów polskich do biskupów niemieckich, [w:] Milenium czy Tysiaclecie, red. B. Noszczak, Warszawa 2006, s. 41-51.

14 J. Mackiewicz, Zwycięstwo prowokacji, Londyn 1983, s. 134-132. Po raz pierwszy praca ukazała się w 1962 r. w Monachium. Stowarzyszenie Pax, prokomunistyczna organizacja, zrzeszająca świeckich działaczy katolickich, utworzona w kwietniu 1952 r.; ośrodkiem organizacyjnym stowarzyszenia był tygodnik „Dziś i Jutro”, wokół którego skupili się działacze przedwojennego Ruchu Narodowo-Radykalnego i Konfederacji Narodu. Pierwszoplanową rolę w organizacji ogrywał Bolesław Piasecki, który w czasie pobytu w więzieniu NKWD (1944-1945) zgodził się na współpracę z komunistami, dywersyjną działalność wobec Kościoła katolickiego w Polsce. 
zerunek ",najeźdźcy”, szukali zewsząd wsparcia, zatem podjęli grę, stosując koncepcję poputniczestwa, zaczerpniętą z NEP-u, którą w Polsce nazywano później „realną polityką". Kluczową rolę w sprawie odegrał Jerzy Borejsza, wówczas wysoki dygnitarz partyjny, bardzo skuteczny w zakresie pozyskiwania do współpracy z komunistami wybitnych przedstawicieli polskiego życia politycznego i kulturalnego (m.in. w dużym stopniu wpłynął zapewne na decyzję powrotu do kraju Melchiora Wańkowicza i Stanisława Cata-Mackiewicza) ${ }^{15}$.

Według zamierzeń Bocheńskiego, był to - jak podkreśla Mackiewicz klasyczny plan ugody między nacjonalizmem i komunizmem. Stworzenie tej dywersyjnej wobec Kościoła agentury stało się pierwszym etapem walki z przeciwnikami politycznymi. Kościół jako organizacja silna i mająca olbrzymie społeczne wpływy, był wrogiem pierwszoplanowym. Zatem Piaseckiego oraz pozostałe dramatis personae, w zamian za życie i dostatnią egzystencję, wykreowano na „legalną opozycję". Następnym etapem była próba zniszczenia Kościoła poprzez całkowite podporządkowanie sobie jego struktur, per analogiam z akcją przeprowadzoną w Moskwie po 1927 r. (gdy zakończył się NEP) wobec Cerkwi prawosławnej. W Polsce sytuacja była jednak niepomiernie trudniejsza, gdyż Kościół miał oparcie także poza granicami kraju w Watykanie ${ }^{16}$.

Tak więc przedstawiciel „myśli konserwatywnej”, niemający zresztą zbyt wielkiego poparcia dla swych przebrzmiałych już mocno idei, przeistoczył się w agenta bolszewickiego, gdyż nie wziął pod uwagę, że centrala komunistyczna w Moskwie nie stanowiła żadnej analogii z zaborczymi monarchiami XIX w., a każdy kompromis prędzej czy później musiał zakończyć się agenturą. „Czasy, gdy prowokator policji carskiej, Azef ${ }^{17}$, uchodził za «króla prowokatorów», odeszły - podsumował nie bez nostalgii J.M. ${ }^{18}$ - Były to czasy indywidualnych agentów i indywidualnych zadań policyjnych. Przyszły czasy masowych agentur i masowych zadań, nie policyjnych ale partyjnych.

15 Jerzy Borejsza (właśc. Beniamin Goldberg), ur. 14 lipca 1905 r., zm. 19 stycznia 1952 r., działacz komunistyczny, publicysta i wydawca. Niemałą rolę, zwłaszcza w pozyskiwaniu działaczy emigracyjnych, odegrali: Dominik Horodyński, później publicysta telewizyjny, i Jan Dobraczyński, pisarz uchodzący za „katolickiego”, którego książki cieszyły się dużą popularnością na Zachodzie i wśród emigracji.

${ }^{16}$ J. Mackiewicz, Zwycięstwo prowokacji, s. 134-142.

17 Jewno Fiszelewicz Azef (1869-1918), prowokator, agent Ochrany w szeregach rosyjskiej partii socjalrewolucjonistów, gdzie był kierownikiem organizacji bojowej. Wydawał członków partii władzom, organizując jednocześnie akty terrorystyczne. Zdemaskowany został przez Władimira L. Burcewa (1862-1942), historyka, należącego także do partii narodników (organizacja Ziemlja i Wola, czyli Ziemia i Wolność); po 1905 r. wstąpił do partii socjalrewolucjonistów; po 1917 r. - w Paryżu był działaczem antysowieckim. Zob. W. Jędrzejewicz, J. Cisek, Kalendarium życia Józefa Piłsudskiego 1867-1935, t. 1, 1867-1918, Wrocław 1994, s. 35, 173.

18 J.M., inicjały, którymi podpisywał Mackiewicz często swoje teksty. 
Na czele jednego z takich kolektywów prowokacji stanął właśnie Piasecki. [...] Gomułka wycofał tylko zagraniczną agenturę «PAX-u», skompromitowaną ostatecznie w katolickich aferach zachodniej Europy, wskutek zdemaskowania jej działalności przez Watykan, i - zastąpił garniturem innych ludzi. A mianowicie ludźmi z grupy Znak-u" ${ }^{\prime 19}$.

O ile grupa Pax-u jawnie i bez żenady kolaborowała z władzami komunistycznymi, o tyle przedstawiciele Znaku czynili to początkowo bardziej subtelnie; dążyli do modus vivendi z rządzącymi, będąc jednocześnie w jak najlepszych relacjach z hierarchią kościelną. Bo też bardziej elastyczne metody walki z religią i Kościołem preferował Władysław Gomułka, a do kompromisu dążył ponadto sam Kościół, który poparł wybory parlamentarne w 1957 r., tym samym bezprecedensowo angażując się we współpracę z władzami. Nadszedł dobry czas dla wszelkich odcieni ugodowców, konformistów i serwilistów. Odtąd zaczęła się rywalizacja między kolaborantami z Pax-u a "faryzeuszami" ze Znaku o względy i pozycję u komunistów. Jedni i drudzy starali się przekonać komunistów o wyższości swojej chęci do współpracy. „Jak wiadomo - komentował Mackiewicz - «przekonać» komunistów nie można; można tylko pasować albo nie pasować do ich taktyki na «danym etapie». A do gomułkowskiego etapu pasuje utrzymanie obydwóch ugrupowań. Piasecki pozostaje w dalszym ciągu «najbogatszym człowiekiem» między Berlinem i Władywostokiem, natomiast na zachód europejski - wysunięty zostaje ZNAK"20. Gomułka dokonał więc jasnego wyboru, z obłudnych katolików uczynił zagraniczną „ekspozyturę prokomunistycznego faryzeizmu". Z pewnością lepiej się prezentowali na zewnątrz, byli bardziej wiarygodni, niż skompromitowani agenci Pax-u. Nastąpiło to po śmierci papieża Piusa XII (9 października 1958 r.) - notabene bardzo konsekwentnego antykomunisty, atakowanego zajadle przez wszystkich protegowanych sowieckich - gdy zgodnie z zaleceniami moskiewskiej centrali, otworzyły się możliwości nowych relacji z Watykanem. Znak otrzymał liczne ułatwienia i koncesje ekonomiczne, a jego członkowie jeździli po Europie, wychwalając „zreformowany” komunizm Gomułki (m.in. bardzo aktywny był Stefan Kisielewski, później czołowy „opozycjonista”). Komunistom przyniosło to olbrzymie korzyści propagandowe, lecz dla piewców „komunizmu z ludzką twarzą" miało opłakane skutki. „Prawo równi pochyłej jest jednak dla wszyst-

${ }^{19}$ J. Mackiewicz, Zwycięstwo prowokacji, s. 141-142. "Znak”, tytuł miesięcznika religijno-kulturalnego, wydawanego w Krakowie od 1946 r. przez świeckich działaczy katolickich, od którego po 1956 r. wywodzi się nazwa ruchu społeczno-politycznego, skupionego także wokół miesięcznika „Więź" i „Tygodnika Powszechnego"; po wyborach parlamentarnych (styczeń 1957 r.) środowisko Znaku utworzyło Koło Poselskie (pięć mandatów) z Jerzym Zawieyskim (członek Rady Państwa), Stanisławem Stommą i Stefanem Kisielewskim na czele; posłem Znaku był m.in. Tadeusz Mazowiecki; zaplecze organizacyjne ruchu stanowiły Kluby Inteligencji Katolickiej.

20 Tamże, s. 147 (rozdział Faryzeizm contra agentura). 
kich - podsumowywał J.M. - Kto na nią raz wskoczy, toczy się dalej. Takoż obserwujemy w tej chwili staczanie się grupy «Znaku-u» $\mathrm{z}$ «etapu politycznego», poprzez «etap faryzeizmu» do etapu jawnej agentury. Świadczy o tym zarówno włączanie się we wszystkie dezyderaty polityki zagranicznej bloku komunistycznego, dywersyjna akcja w ośrodkach katolickich na Zachodzie, jak też w ośrodkach emigracyjnych" 21 .

Ważnym i bardzo znamiennym efektem aggiornamento były zmiany personalne, symboliczne wręcz dla sprawy relacji Kościoła w kraju z Watykanem. Mackiewicz nazywa to - znów nader słusznie - końcem wielkiej tradycji. Istotnie tradycja była niemała, sięgała bowiem czasów Rzeczypospolitej Obojga Narodów (Korony i Litwy). W Stolicy Piotrowej rezydował „od zawsze" przedstawiciel dyplomatyczny Rzeczypospolitej. Ostatnim spośród długiego szeregu polskich przedstawicieli był Kazimierz Papée, mianowany na to stanowisko przez prezydenta Ignacego Mościckiego 14 lipca 1939 r. Jego rola wzrosła niepomiernie w czasie II wojny światowej. Wskutek najazdu niemiecko-sowieckiego na Polskę we wrześniu 1939 r. reprezentował Rząd Rzeczypospolitej na Uchodźstwie. Uznawany był przez papieża Piusa XII, a jako najstarszy wiekiem sprawował też godność dziekana korpusu dyplomatycznego przy Stolicy Apostolskiej. „Stan ten - zaznacza Mackiewicz był cierniem w oku i jedną z przyczyn nieustannych napaści na Watykan ze strony mieniących się suwerennych rządem - komunistycznych uzurpatorów w Warszawie. A też nacisku na episkopat polski, aby wpływał w Rzymie na cofnięcie uznania ambasadzie emigracyjnego rządu polskiego" ${ }^{22}$. Wszak 12 września 1945 r. tzw. Tymczasowy Rząd Jedności Narodowej zerwał konkordat z Watykanem, będący podstawą wzajemnych relacji od 1925 r. $^{23}$ Zmiana status quo stała się jednak możliwa dopiero $\mathrm{w}$ okresie aggiornamento. Ambasador polski stał się ostatnim zamykającym tradycję posłów przy Stolicy Apostolskiej. Jan XXIII przestał go uznawać ambasadorem i nadał status "kierownika spraw" (gerente degli affari - Administrator Spraw Ambasady RP przy Stolicy Apostolskiej). Nastąpiło to w 1958 r. ${ }^{24} \mathrm{~W}$ sprawie istotną rolę odegrał prymas Wyszyński, „który w ten sposób umacniał swoje stanowisko w układzie z pierwszym sekretarzem komunistycznej partii, Gomułką"25. Jednakże w miarę coraz "realniejszych” stosunków między Watykanem i stolicami w Moskwie oraz Warszawie nawet owo gerente degli affari, bar-

${ }^{21}$ Tamże, s. 151.

22 J. Mackiewicz, Watykan w cieniu, s. 301.

${ }^{23}$ Konkordat między Stolicą Apostolską a Rzecząpospolitą zawarto w Rzymie 10 lutego $1925 \mathrm{r}$.

${ }^{24}$ Kazimierz Papée pełnił ową niejasną i osobliwą funkcję do 1972 r., następnie - do 24 maja 1976 r. - był jedynie nieoficjalnym przedstawicielem Rządu RP na Uchodźstwie. Zmarł w Rzymie 19 stycznia 1979 r.

25 J. Mackiewicz, Watykan w cieniu, s. 301-302. 
dzo przecież nominalne i symboliczne, było dla komunistów za dużo. Tak więc na drodze „normalizacji” $i$ „,polepszania” atmosfery między „Kościołem i Państwem” 19 października 1972 r. watykański sekretarz stanu, czyli minister spraw zagranicznych, poinformował ambasadora Papée, że kierownictwo sprawami Polski przy Watykanie dobiegło końca ${ }^{26}$.

W lipcu 1974 r. powołano Zespół do spraw Stałych Kontaktów Roboczych między PRL a Stolicą Apostolską, a od jesieni 1974 r. rząd PRL wysyłał swoich przedstawicieli do Watykanu, którzy rezydowali w ambasadzie PRL przy Republice Włoskiej. Ten osobliwy stan trwał do schyłku rządów komunistycznych w Polsce.

Kard. Stefan Wyszyński, represjonowany przez komunistów, przez trzy lata więziony (od 25 września 1953 r. do 28 października 1956 r.), ściśle stosował się do reguł aggiornamento. Gdy przybył do Watykanu w związku z pracami soborowymi, przyjęty został dwukrotnie przez Jana XXIII, po raz pierwszy już następnego dnia po przylocie do Rzymu, 17 lutego 1962 r. „W kilka dni później, podczas drugiej audiencji, która trwała całą godzinę, papież, błogosławiąc z okna zebrany na placu tłum wiernych, ukazał się z kardynałem Wyszyńskim. Źródła watykańskie zaznaczyły, że tego rodzaju wyróżnienie jest bez precedensu. W piątek, dnia 23 lutego, kardynał Wyszyński - ignorując jak zawsze b. ambasadora polskiego przy Watykanie, Kazimierza Papée, obecnie pełniącego funkcję «kierownika spraw» z ramienia polskiego rządu emigracyjnego - złożył o godzinie 16-tej oficjalną wizytę ambasadorowi Polski komunistycznej przy Kwirynale, Adamowi Willmannowi" ${ }^{27}$.

Tymczasem papież Jan XXIII zmarł niespodziewanie 2 czerwca $1963 \mathrm{r}$. „Wśród licznych depesz kondolencyjnych otrzymanych przez Święte Kolegium w Rzymie, jedna z pierwszych nadeszła z wyrazami głębokiego żalu od sekretarza sowieckiej partii komunistycznej Nikity Chruszczowa"28. Jego następcą został 21 czerwca 1963 r. kard. Giovanni Battista Montini, który przybrał imię Paweł VI.

Prymas Wyszyński obmyślił drogę wielkiej odnowy duchowej narodu i Kościoła w Polsce, co miało niewątpliwy związek z sytuacją politycznej opresji, w jakiej znaleźli się Polacy po II wojnie światowej. Opracował wówczas program Wielkiej Nowenny Chrztu Polski i Sacrum Poloniae Millenium. Ponadto 16 maja 1956 r. napisał tekst ślubów narodowych, które miały być odnowieniem królewskich ślubów lwowskich Jana Kazimierza w ich trzechsetną rocznicę. 26 sierpnia 1956 r. pielgrzymom (ok. jednego mln) zebranym na Jasnej Górze odczytał je bp Michał Klepacz, pełniący obowiązki prze-

26 Tamże, s. 302.

27 Adam Willmann (1908-1995), dyplomata państwa komunistycznego, w latach 1962-1967 ambasador PRL we Włoszech.

28 J. Mackiewicz, Watykan w cieniu czerwonej gwiazdy, Warszawa 1990, s. 7. Pracę wydano po raz pierwszy w Londynie w 1975 r., jest kontynuacją W cieniu Krzyża. Kabel Opatrzności. 
wodniczącego Episkopatu Polski. Przez kolejne dziewięć lat poprzedzających Milenium Kościół w Polsce miał odnowić własne oblicze. Wymagał tego trudny, wyjątkowy czas konfrontacji narzuconej przez totalitarne państwo ${ }^{29}$. Początek Wielkiej Nowenny nastąpił w dzień szczególny - Święto Matki Bożej Królowej Polski, w niepodległej Rzeczypospolitej święto narodowe, dzień pamiętny wielkimi wydarzeniami historycznymi, $w$ tym przede wszystkim majową Konstytucją 1791 r. - 3 maja 1957 roku na Jasnej Górze w obecności prymasa. W dwa dni później, w niedzielę zainicjowano Wielką Nowennę we wszystkich parafiach w Polsce. Wielkie uroczystości zakończono w $1966 \mathrm{r}^{30}$

Pretekstem do realizacji powyższego zamierzenia stał się więc koniec obrad soboru watykańskiego II i zaplanowane na połowę 1966 r. główne obchody na Jasnej Górze. Z tej okazji obecni na soborze biskupi polscy wystosowali 56 listów do konferencji episkopatów różnych krajów, zawiadamiających o tysiącleciu chrztu Polski i proszących o modlitwę w intencji powodzenia przygotowywanych z tej okazji uroczystości. Wśród wystosowanych wówczas pism znalazło się również datowane na 18 listopada 1965 r. Orędzie biskupów polskich do ich niemieckich braci w Chrystusowym urzędzie pasterskim ${ }^{31}$. Spór między państwem komunistycznym a Kościołem dotyczył najważniejszych problemów ideowych, kulturowych, a nawet cywilizacyjnych w ówczesnym państwie polskim: stosunków państwo-Kościól, relacji polsko-niemieckich i konfliktów wewnątrzpartyjnych w PZPR. Osadzony był także w skomplikowanej sytuacji międzynarodowej. Określała go „zimna wojna” oraz podział Europy na blok wschodni i zachodni. Niemcy Zachodnie nie uznawały granicy polsko-niemieckiej i obowiązywała u nich doktryna Hallsteina ${ }^{32}$.

Orędzie sprawiło jednak, iż jego relacje z rządem komunistycznym we własnym kraju pogorszyły się nagle w 1966 r. Kryzys, chociaż krótkotrwały - Mackiewicz nazwał to "krótkim spięciem roku 1966” - stał się widoczny i brzemienny w następstwa polityczne. Ujawniło ono wykładnię tego, jak komuniści rozumieli „stosunki Kościoła i Państwa” oraz jak „polityczne występowanie Kościoła". Episkopat ze swej strony deklarował powstrzymy-

${ }^{29}$ Nowenna w rozumieniu potocznym to nabożeństwo do Matki Bożej Nieustającej Pomocy. Termin rozszerzono, nadając mu charakter wielkiego, zbiorowego nabożeństwa Polaków, które miało być drogą do odnowy wiary i jej umocnienia.

${ }^{30} \mathrm{~J}$. Miłosz, Założenia i realizacja Wielkiej Nowenny na przykładzie archidiecezji gnieźnieńskiej i poznańskiej,

[w:] Milenium kontra tysiaclecie - 1966, pod red. K. Białeckiego, S. Jankowiaka i J. Miłosza, Poznań 2007, s. 18.

31 A. Dudek, Państwo i Kościół w Polsce 1945-1970, Kraków 1995, s. 181.

32 Po ustanowieniu stosunków dyplomatycznych z ZSRS kierownik Wydziału Politycznego w MSZ Wilhelm Grewe opracował na zlecenie sekretarza stanu Waltera Hallsteina memorandum, którego treść sprowadzała się do tezy, że rząd federalny winien odtąd traktować każde nawiązanie przez państwa trzecie stosunków dyplomatycznych z NRD za akt nieprzyjazny wobec RFN. Tezę tę zaczęto wkrótce potem nazywać doktryną Hallsteina. 
wanie się od wystąpień politycznych, a stanowisko to pokrywało się z intencjami partii komunistycznej. Jednakże - pisze Mackiewicz - były od tej reguły wyjątki. Dopuszczano akty polityczne ze strony hierarchów kościelnych wówczas, gdy były zbieżne $\mathrm{z}$ intencjami partii. Tak było w przypadku licznych wystąpień episkopatu, zarówno w kraju, jak też na forum międzynarodowym, na rzecz uznania granicy polsko-niemieckiej. Istotne były zwłaszcza zabiegi w Rzymie na rzecz uznania tej granicy przez Stolicę Apostolską. Przecież w tym samym 1965 r. abp Bolesław Kominek, współinicjator i autor Orędzia, wystąpił na łamach "Tygodnika Powszechnego" (31 maja) z obszernym artykułem uzasadniającym prawa Polski do Ziem Zachodnich, a prymas Wyszyński wygłosił w Łodzi „z ambony Kościoła Św. Panny Marii podniosłe kazanie o «wiecznej przynależności do Polski Ziem Odzyskanych», wplatając w nie silne polityczne akcenty. We Wrocławiu odbywały się nabożeństwa, w których celebrant przed ołtarzem przybrany był nawet - rzecz przedtem $\mathrm{w}$ Polsce nigdy nie praktykowana - w ornat w emblematami państwowymi... Mimo, oczywiście, politycznej treści tych wystąpień, nie zostały one «politycznie» poczytane" 33 .

Polityczny kontekst Orędzia był bardzo szeroki, gdyż wykraczał poza granice państwa i miał swe konotacje międzynarodowe. To także polemika $\mathrm{z}$ antyniemiecką propagandą $\mathrm{w}$ komunistycznej Polsce, bardzo istotną częścią zwłaszcza okresu rządów Władysława Gomułki w latach 1956-1970. Granica na Odrze i Nysie stała się tylko politycznym pretekstem propagandowym całej sprawy, podobnie jak rzekome zagrożenie ze strony „rewizjonizmu niemieckiego". Chodziło oczywiście o niezmienny cel komunistów, czyli opanowanie świata, a najpierw Europy, najważniejszej politycznie - mimo wszystko - części Zachodu. Po opanowaniu Polski bowiem zachodnia część Niemiec stanowiła ostatnią przeszkodę na drodze do realizacji tego celu.

Komuniści zamierzali to uczynić wszelkimi środkami, nie wyłączając doprowadzenia do nowego "Rapallo”, a także taktycznego sojuszu z czynnikami antysowieckimi w Europie. Granica na Odrze i Nysie stała się tylko politycznym pretekstem propagandowym całej sprawy, podobnie jak rzekome zagrożenie ze strony „rewizjonizmu niemieckiego”. Ponieważ jednak Polska utraciła suwerenność państwową, nie można jednocześnie utożsamiać wytworzonych $\mathrm{w}$ wyniku tej utraty nowych linii granicznych z suwerenną granicą państwową - podkreślał J.M. „Skoro Polska cała utraciła niepodległość, nie mogła jednocześnie «odzyskiwać» jakichś ziem", gdyż byłoby to nielogiczne.

Wytyczona zaiste genialnie przez Stalina linia graniczna była w istocie jedynie wewnętrzną linią rozgraniczającą „Polskę Ludową” od komunistycznej części Niemiec. W ten sposób powstała trwała przepaść między Polakami

${ }^{33}$ J. Mackiewicz, Watykan w cieniu, s. 256-257. 
a Niemcami, lecz z drugiej strony - rzecz politycznie o wiele dla komunistów istotniejsza - "zalegalizowano" PRL jako suwerenne "państwo", "gdyż tylko przez uznanie państwa polskiego dochodzi się do uznania Odry-Nysy jako granicy państwowej" ${ }^{34}$. W jaki sposób znajdująca się całkowicie pod kuratelą NATO i Stanów Zjednoczonych Republika Federalna Niemiec mogłaby zagrozić Polsce lub „pokojowi światowemu”? Tego żaden komunistyczny publicysta nie był w stanie przekonywająco wyjaśnić.

$\mathrm{W}$ ten sposób jeden, zresztą nie najistotniejszy odcinek granicy, stał się ważniejszy od niepodległości. Tu właśnie tkwi sedno sprawy. Debaty nad odzyskaniem granicy prowadzono w kręgach "polrealistów”, a także np. na łamach paryskiej „Kultury” (nr 12/170 z 1961 r.), gdzie zastanawiano się nad granicą na Odrze i Nysie, stosując dwie miary wobec problemu całości polskiego terytorium pojałtańskiego. Chodzi o to, że mówi się przyciszonym głosem lub nie wspomina w ogóle o kwestii odzyskania kresów wschodnich Rzeczypospolitej, tych zagwarantowanych traktatem ryskim z 1921 r. Idąc tropem propagandy komunistycznej, zauważyć należy, iż milczy się też na temat odzyskania Królewca i północnej części Prus Wschodnich, należących jeszcze w 1657 r. jako lenno do Korony (bo należą do Sowietów!), a gromko rozprawia się o ziemiach utraconych sześćset lat temu. Fałsz i zakłamanie argumentacji oraz samego postulatu dorównują także drugiemu hasłu propagandowemu mówiącemu o „zagrożeniu ze strony rewizjonizmu niemieckiego". W jaki sposób, zastanawiał się J.M., znajdująca się całkowicie pod kuratelą NATO ${ }^{35}$ i Stanów Zjednoczonych Republika Federalna Niemiec mogłaby zagrozić Polsce lub „pokojowi światowemu”? „W zaistniałej sytuacji, gdy Polska cała znajduje się w niewoli komunistycznej, i nikt jej na razie nie zamierza wyzwolić, apele tych Polaków, którzy wzywają wolny świat, aby ich bronił przed «rewizjonizmem» niemieckim - zakrawają na tragiczną groteskę"36. Naprawdę trudno odmówić słuszności zaprezentowanemu tokowi rozumowania.

Problemu niemieckiego jednak nie lekceważył. Prawdziwy, a nie pozorny „problem niemiecki” i zagrożenie polegały na czymś innym, na instrumentalnym wykorzystaniu tego propagandowego hasła $\mathrm{w}$ celu realizacji jasno określonego celu politycznego. Jeżeli bowiem Polsce miałoby grozić niebez-

${ }^{34}$ J. Mackiewicz, Zwycięstwo prowokacji, s. 179.7 grudnia 1970 r. w Warszawie podpisano (komunistyczny premier Józef Cyrankiewicz i kanclerz Willy Brandt) układ o podstawach normalizacji stosunków polsko-niemieckich. RFN uznała zachodnią granicę Polski na Odrze i Nysie. Oba państwa wzajemnie się uznały i nawiązały ze sobą stosunki dyplomatyczne.

${ }^{35}$ NATO (ang.): North Atlantic Treaty Organization (Pakt Północnoatlantycki); układ wojskowo-polityczny zawarty 4 kwietnia 1949 r. w Waszyngtonie - w obliczu zagrożenia komunistycznego - między demokratycznymi państwami europejskimi, Stanami Zjednoczonymi i Kanadą (początkowo dwanaście państw).

${ }^{36}$ Tamże, s. 184. 
pieczeństwo ze strony Niemiec - jak chcą komuniści - to w sposób oczywisty należy szukać oparcia w Sowietach. Zatem komuniści bardzo konsekwentnie przeciwstawiali się idei Wiedervereinigung - ponownego zjednoczenia Niemiec. Ponadto prawdziwe zagrożenie niemieckie polegało na wykorzystywaniu Niemców w grze między komunizmem a światem zachodnim. Walka bowiem toczy się nie o wolność tego czy innego narodu, lecz o rzecz o wiele istotniejszą - o wolność człowieka, zagrożoną przez międzynarodowy komunizm i coraz bardziej skuteczne metody prowokacji ${ }^{37}$. Komunizm był dla Mackiewicza rodzajem ciężkiej i rozprzestrzeniającej się choroby społecznej, zarazy wpływającej destrukcyjnie na całą ludzkość.

Interesujący był także międzynarodowy kontekst wystąpienia polskich biskupów. Trwała zimnowojenna konfrontacja. Niedawno miała miejsce wizyta w Republice Federalnej Niemiec prezydenta Stanów Zjednoczonych Johna F. Kennedy'ego w konsekwencji tzw. drugiego kryzysu berlińskiego wywołanego budową przez władze NRD muru berlińskiego (13 sierpnia 1961 r.). Komunistyczne państwo niemieckie ustanowiło w ten sposób swoją granicę państwową w mieście. Przybyli wówczas do Niemiec dziennikarze z niemal całego wolnego świata przyczynili się do nagłośnienia wizyty amerykańskiego prezydenta i nierozwiązanego problemu niemieckiego. W czasie pobytu w Berlinie Zachodnim - 26 czerwca 1963 r. - prezydent Kennedy demonstracyjnie przybył w pobliże Bramy Brandenburskiej i wygłosił słynne, powtarzane wielokrotnie $w$ mediach przemówienie, $w$ którym powiedział po niemiec$\mathrm{ku}$, że czuje się berlińczykiem („Ich bin ein Berliner") ${ }^{38}$.

Tymczasem 13 stycznia 1966 r. w Audytorium Palazzo Pio w Rzymie odbyła się w obecności Ojca Świętego Pawła VI główna uroczystość milenijna, na której zabrakło jednak prymasa Wyszyńskiego, inicjatora i autora koncepcji obchodów milenijnych. W ramach represji bowiem władze komunistyczne nie udzieliły pozwolenia na wyjazd prymasa do Watykanu. Prof. Oskar Halecki, znakomity historyk polski, ceniony przez papieży Piusa XII i Jana XXIII, przebywający od II wojny światowej na emigracji, wygłosił podczas uroczystości w owym doniosłym dniu znakomite wystąpienie po łacinie, zatytułowane Pierwsze tysiąclecie katolickiej Polski ${ }^{39}$. Reprezentował Polskę niepodległą, zarówno Polaków przebywających na emigracji, jak i w kraju. Wykład trwał ponad godzinę. Halecki, doskonały i ceniony znawca późne-

37 Tamże, s. 204-210 (rozdz. Prawdziwe zagrożenie niemieckie); por. G. Łukomski, dz. cyt., s. $153-154$.

38 Por. G. Łukomski, Aleksander Bergman (1906-1967). Życie niedokończone, Poznań-Warszawa-Londyn 2012, s. 78-82.

${ }^{39}$ Tekst wystąpienia zamieszczono w "L' Osservatore Romano" oraz opublikowano w formie broszury: O. Halecki, Pierwsze tysiaclecie katolickiej Polski, Roma 1966. Zamieścił je także Janusz Cisek w swojej książce Oskar Halecki: historyk, szermierz wolności, Warszawa 2009, s. $58-74$. 
go średniowiecza i czasów nowożytnych, dokonał wnikliwej retrospektywy dotyczącej tysiącletnich dziejów Polski i roli Kościoła katolickiego w kształtowaniu polskiej państwowości, poczynając od chrztu dokonanego przez Mieszka I w 966 r.

Józef Mackiewicz zdecydowanie popierał Orędzie biskupów z listopada 1965 r. jako głęboko ewangeliczne i mądre oraz z całą pewnością apolityczne. Wobec bezspornego faktu, iż to Niemcy wywołały II wojnę światową, a nie odwrotnie, i wyrządziły Polsce znane powszechnie krzywdy, słowa episkopatu polskiego powtarzają tylko "słowa wypowiadane w modlitwie przez cały świat chrześcijański: «jako i my odpuszczamy naszym winowajcom»". W ten sposób - jak sądził - były może jednym z najwznioślejszych ze znanych w stosunkach międzynarodowych aktów chrześcijaństwa. I takimi winny były pozostać, w odpowiedzi „na bezprzykładną nagonkę z początków roku 1966 przez reżym komunistyczny" 40 .

Lecz właśnie ono wywołało prawdziwą burzę i dosłownie wściekły atak na kard. Wyszyńskiego ze strony propagandy partyjnej z powodu „polityczności" wystąpienia hierarchów. Wyszyńskiemu cofnięto paszport dyplomatyczny, którego udzielano mu zwykle na podróż do Rzymu, a ponadto wypomniano mu, iż każdorazowo zabierał ze sobą z przyzwoleniem władz tysiąc dolarów na podróż.

Konkluzja wypadła tyleż jednoznacznie, co prawdziwie. Apolityczność Kościoła, „jest to teoretyczna legenda, której nikt nie bierze w praktyce poważnie. Kościół angażował się zawsze i angażuje w dalszym ciągu w sprawy polityczne". Jako dowód przytoczył jeden, lecz wiele mówiący przykład, dotyczący stosunku Watykanu do państw dokonujących masowych zbrodni w czasie II wojny światowej. Potępiono wprawdzie zbrodnie niemieckie, mimo że Pius XII zbyt słabo protestował w tej sprawie w czasie wojny, znajdując się jednakże w opresji reżimów włoskiego i niemieckiego, a z drugiej strony - w imię „apolityczności” Kościół przemilcza identyczne zbrodnie innych państw, wśród nich zbrodnie sowieckie. Tak więc apolityczność Kościoła jest fikcją, gdyż Kościół jako instytucja nie może pozostawać na uboczu spraw świata doczesnego. Błąd polskiego episkopatu polegał na swoistym uprzedzaniu oczekiwań władz komunistycznych, zapewne w zamian za jakieś koncesje i w imię poszukiwania modus vivendi, wszak zawsze był odpowiedzialny za los wiernych ${ }^{41}$.

Podsumował czytelną, lecz subtelnie podaną aluzję dotyczącą zmian mentalnościowych i społecznych, jakie przyniósł bolszewizm, głębokim gorzkim komentarzem: „Bez usunięcia największego w dziejach antywolnościowego

\footnotetext{
40 J. Mackiewicz, Watykan w cieniu, , s. 257.

41 J. Mackiewicz, List Pasterski, „Wiadomości” (Londyn) 1969, nr 1199 z 23 marca. Tekst także w: J. Mackiewicz, B. Toporska, Droga Pani..., s. 345-355.
} 
uzurpatora nie da się, niejako służbowymi schodami, przywrócić wolności i w naszym domu. Wszelako proste rozpoznanie utrudnia okoliczność, że ludzi nawykłych chodzić służbowymi schodami - których zawsze bywało bardzo dużo na świecie - rozmnożyło się dziś niepomiernie. Kiedyś używało się ich do posług; dziś nadają ton Duchowi Czasu"42.

Walka z Kościołem i religią wpisana była - jako się rzekło - w ramy ideologii komunistycznej. Państwo totalitarne bowiem nie tolerowało żadnych obszarów życia społecznego, nad którymi nie sprawowałoby kontroli. Po zdławieniu podziemia niepodległościowego rola najtwardszego oponenta i zarazem głównego wroga jedynej siły politycznej w państwie, Polskiej Zjednoczonej Partii Robotniczej, na drodze realizacji założeń ideologicznych przypadła Kościołowi rzymskokatolickiemu. Mackiewicz jeden z niewielu otwarcie mówił także o kryzysie w najstarszej na obszarze cywilizacji zachodniej instytucji.

Grzegorz Łukomski

\title{
Państwo komunistyczne a Kościół w publicystyce Józefa Mackiewicza
}

\begin{abstract}
Streszczenie
Walka z Kościołem i religią wpisana była w ramy ideologii komunistycznej. Państwo totalitarne nie tolerowało bowiem żadnych obszarów życia społecznego, nad którymi nie sprawowałoby kontroli. Po zdławieniu podziemia niepodległościowego rola najtwardszego oponenta i zarazem głównego wroga jedynej siły politycznej w państwie, Polskiej Zjednoczonej Partii Robotniczej, na drodze realizacji założeń ideologicznych przypadła Kościołowi rzymskokatolickiemu. Mackiewicz, jako jeden z niewielu, otwarcie mówił także o kryzysie wartości w najstarszej na obszarze cywilizacji zachodniej instytucji.
\end{abstract}

\section{Struggle between the communist state and the Catholic Church as presented in political works by Józef Mackiewicz}

\begin{abstract}
The combat against the Church and religion was an essential element of the communist ideology. The totalitarian state disapproved of any and all fragments of the social life escaping its control. Upon suppression of the underground independence movement, the Roman Catholic Church accepted the role of the most vigorous opponent, and hence the main enemy of the one and only political authority in the country - the Polish United Workers' Party - and its ideological principles. Furthermore, Mackiewiczas one of few people who openly talked about a crisis of values in the oldest institution within the frames of the Western civilisation.
\end{abstract}

42 Tamże, s. 356. 